\title{
台風0514号時の宮崎県を事例とした地方自治 体の防災管理体制の現状と兴の強化について \\ CASE STUDY ON DISASTER MANAGEMENT SYSTEM OF SELF-GOVERNING COMMUNITIES AND THEIR REINFORCEMENT IN MIYAZAKI PREFECTURE THROUGH T0514
}

\author{
村上啓介 ${ }^{1} \cdot$ 杉尾哲 2 \\ Keisuke MURAKAMI and Satoru SUGIO \\ 1正会員 工博 宮崎大学助教授 土木環境工学科 ( ₹ 889-2192 宮崎市学園木花台西 1-1) \\ 2正会員 工博 宮崎大学教授 土木環境工学科（（８89-2192 宮崎市学園木花台西 1-1)
}

\begin{abstract}
This paper deals with an investigation of a disaster management system of self-governing communities against a natural disaster through a questionnaire survey after T0514 that brought the most serious damages in Miyazaki prefecture widely. Many self-governing communities delay their official announcement of evacuation instruction and directive. One of the reasons is that the most of those selfgoverning communities have no objective criteria for their official announcement. The disaster information that covers a narrow area is desired to announce the evacuation instruction and directive at the best opportunity. The risk communications for natural disaster such as landslide and flood are not sufficient between self-governing community and residents, and improvement of this communication is desired to derive an appropriate evacuation against the natural disaster that exceed a maximum credible level.
\end{abstract}

Key Words : Natural disaster, disaster information, risk communication, evacuation instruction, evacuation directive

\section{1 .はじめに}

九州西岸を北上した大型で非常に強い台風14号は平成 17年9月4日から6日にかけて東九州一体に記録的な豪雨 をもたらした。乥の特徵は, 宮崎県東臼杵郡美郷町（旧 南郷村) に設置された気象庁の神門観測所て積算雨量が 1, 322nm 二達するなど ，広範囲における過大な積算雨量 に伴う河川災害の甚大さと重大な土砂災害発生箇所の多 さである ${ }^{1)}$. 兴のため, 宮崎県内の300市町村で自主避 難，28の市町村て避難勧告，13の市町村で避難指示力発 令された (表-1参照 :合併前の市町村名て記載)．宮崎 県の発表によると, 県内での死者数は13名 , 全壞家屋は 1, 104棟，半壤家屋は3, 284棟，床上浸水は1，462棟，床 下浸水は2, 919棟であった ${ }^{2)}$.

今回の過去にない広範で重大な災害発生のもとで, 水 害や土砂災害に対する防災施設整備の遅れとともに，避 難勧告や避難指示の発令基準の整備の遅れ，避難に結び つく災害情報の内容や伝達方法のあり方，狭域を対象と した災害情報の重要性，日頃からの危険情報の把握や住 民への周知不足，行政と住民間における防災意識の共有
表-1 平成17年台風14号における宮崎県内市町 村の避難勧告・指示の発令状況

\begin{tabular}{|c|c|}
\hline 自主避難 & 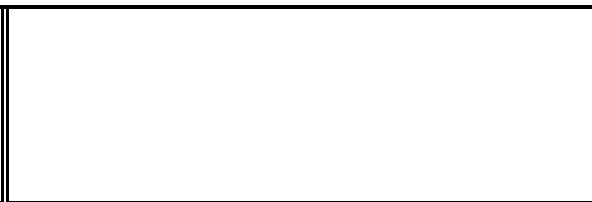 \\
\hline 避難勧告 & 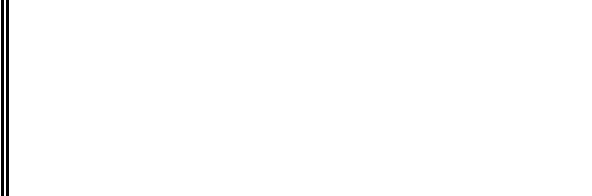 \\
\hline 避難指示 & \begin{tabular}{|l} 
高鍋町, 東郷町, 国富町, 都農町, 西都市, \\
門川岡市, 高岡町, 新富町, 椎葉村, 諸塚村, 宮崎市，
\end{tabular} \\
\hline
\end{tabular}

不足等, 数多くの問題点力指摘された .

このような記録的豪雨による風水害や土砂災害が再び 発生しないとは言えない，光の中で，住民の避難に直接 的に関わる市町村の色機管理体制の現状を把握して問題 点を明らかにすることは, 今後の大規模自然災害に対す 
設問5)関係機関 宮崎県他)から提供される河 川水位や降雨量に関する災害情報は，避難勧 告や避難指示の発令の判断に有効に利用され ましたか．複数回答可)

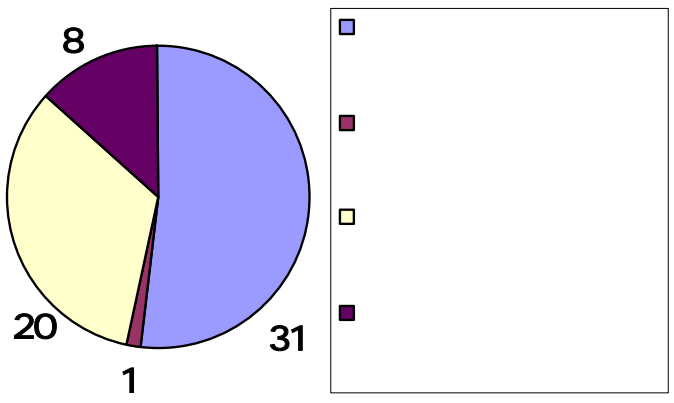

図 - 1 災害情報の避難勧告・指示の発令への活用

る地方自治体の防災管理体制のあり方や強化策を検討す る際に重要と考える . 本論文では, 宮崎県内の全市町村 を対象に台風14号来襲時の災害対応に関するアンケート 調査を実施し，大規模自然災害に対する地方自治体の防 災管理体制の現状と問題点を整理すると伴に，今後の強 化のあり方で重要と考えられる事項について検討した結 果を示す。

\section{2 . 防災管理体制に関するアンケート調査方法}

アンケート調査は，宮崎県内の全市町村（合併前の44 市町村) の防災担当者宛てに, 台風後の平成17年10月中 旬に調査用紙を送付し, 記入後に返送してもらう形式で 実施した .アンケートの内容は，(1)避難傕告や避難指示 の発令日時と地区名 , (2)全体を統括した災害対応組織の 形態, (3)河川水位や降雨量等の災害情報の受信・伝達の 問題点，(4)地域防災計画及ひ独自の防災マニュアルの整 備状況，(5)避難勧告・避難指示の発令基準の設定状況， 6避難勧告や避難指示の住民への伝達の問題点，77日頃 からの危険情報の把握と周知について，8防災訓練や防 災教育の実施状況，(9)自主防災組織の現状，(10)今後の防 災体制のあり方に関する37項目である . 今回の調査では 全ての市町村から回答を得た . アンケートは選択と記述 からなり，回答に不明な点がある場合には担当者に電話 連絡をして内容を確認した。

\section{3. アンケート調査の結果と考察}

（1）避唯勧告・指示の発令と伝達について

図一1は，気象台や宮崎県から提供される災害情報 (降雨量や河川水位) の避難勧告や避難指示発令への活 用について複数回答してもらつた結果を示したものであ る.31の自治体が災害情報を有効に活用できたと回答し ている一方で, 200自治体では, 地区単位での発令に対
設問11) 14)避難勧告や指示を発令するためめの 河川水位や降雨量等の基準值を設定しています か。

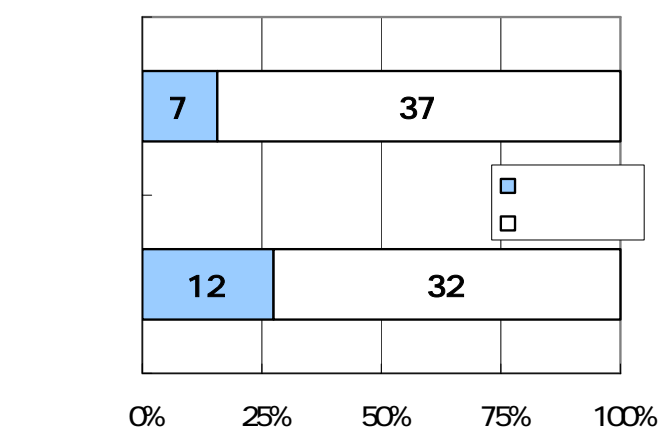

图 - 2 避難勧告・指示の発令基準の整備状況

して現行の災害情報が広域過ぎ，勧告等の発令の判断に 苦慮したと回答している。

危険箇所を多く抱える県北のある自治体では，「現状 ては区域を細分化した雨量情報は得られず、『土砂災害 発生の危険性か高い』という情報は村全体を範囲として 認識するしかなく、弚の情報に従って村全体の住民を避 難させることは困難であり，現状の災害情報では避難勧 告や避難指示につながりにくい」と指摘している .

図一2は，避難勧告および避難指示を発令する際の基 準の設定状況を示したものである . 客観的な基準值の設 定は, 平成16年の豪雨災害においても重要な課題の一つ として取り上げられた ${ }^{3)}$. 今回のアンケート調査では， 12の自治体 (全体の約 $27 \%$ ) が具体的な避難勧告の発令 基準を設定していると回答し，7の自治体（全体の約 16\%) が避難指示に対しても基準值を設定していると回 答している. 具体的な基準のほとんどは河川水位に係わ るもので「○○橋の水位が $\triangle \mathrm{m} 」$ 等の記述である .

一方，土砂災害について客観的な基準值を記述した自 治体は見当たらず, 降雨量や土壤雨量指数等を参考にし ながら現場の状況と過去の経験から判断しているようで ある. 牛山ら ${ }^{4)}$ は, 市町村が避難勧告や避難指示を発令 する際に, 被害の発生を目安にする場合が多いことを指 摘している.今回の災害においても11名が土砂災害て犠 牲となったが, 避難勧告や避難指示の発令は被害発生後 であった . 㴥方庁では，避難勧告・指示の発令に対する 客観的な基準を設定している自治体は, 洪水災害に関し ては2006年3月時点で全体の約30\%, 土砂災害に関しては 約20\%と報告している5)

図－3は，市町村から住民への避難勧告や避難指示の 発令タイミングに関する結果を示したものである.設問 では, 発令のタイミングを判断する具体的な定義は指定 せず，担当者の総合的な判断結果として評価した .

「適切なタイミングで発令できた」と評価したのは22 の自治体 (全体の50\%) にとどまった．無回答は「タイ ミングが谪切であったとは判断できなかった」と解釈す ると, 発令基準を設定している自治体でも半数はタイミ 
設問17)住民への避難勧告や避難指示の発令 に関して ,該当する番号に○印を付けてください，

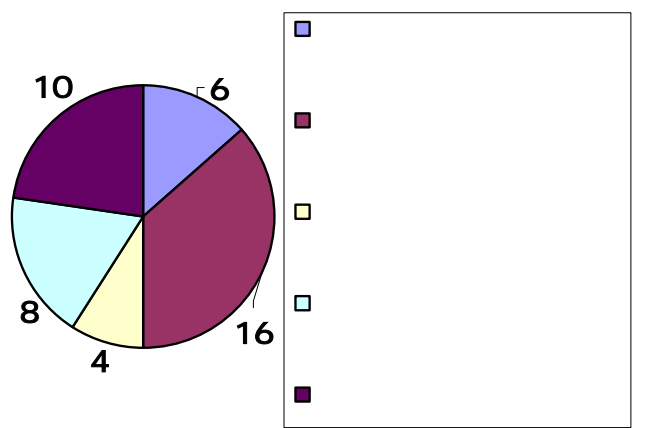

図 -3 避䧼権告・指示の発令タイミングについて

設問19)避難勧告や避難指示は住民へ確実に 伝達されましたか．
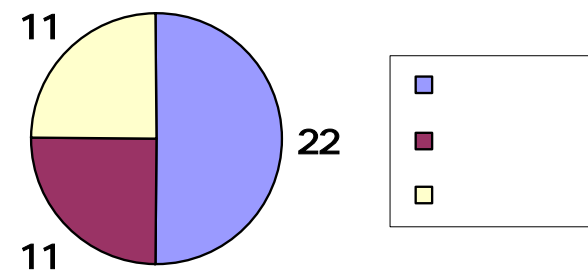

図-4 避難勧告・指示の住民への伝達状況

ングに問題力残つたと自己評価していることになる．

また，今回の台風14号時に土砂災害で人的被害力溌生 した自治体ては，避蜼败梏や避蜼指示の発令基準を設定 しおらず，図ー3においても発令のタイミングに問題が 残つたと評価している. 兴の理由として, 現行の降雨情 報か空間的に踈であるため，地区別の判断への利用か涃 難なことや , 危険個所単位て地滑りの危険度を適切に評 価する手段がいいとを挙げている .さらに, 今回の台 風では危険個所以外でも土砂崩壊によって犠牲者か複数 名出ている．危険個所の指定の見直しを含め，狭域の気 象情報か浰用できるシステム整備，狭域の情報をもとに した危険度評価手法の構筑 , 弚れらの避難勧告や避難指 示の発令基準への活用力課題として挙げられる.

図－4は，避難勧告や避難指示の住民への確実な伝達 について示したものである. 半数の自治体は「避難勧告 や避難指示は住民に確害に伝達された」と自己評価して いる．一方，無回答は「避難情報力確実に伝達されたと は判断できなかった」と解䣋すると，残りの半数の自治 体は住民への確実な伝達に問題を感じていることになる． 特に，図ー3で「避蜼情報の発令のタイミングに問題が 残つた」と回答した自治体のうち94\%の自治体が「住民 に確実に伝達されたとは思わない」と回答している .

一方で，「避難勧告・指示が適切なタイミングで発令 できた」と回答した自治体のうち73\%の自治体が「避難
設問21)地域のハザードマップ 危険個所，避難 場所，避難経路等を記したマップ) を作成してい ますか．

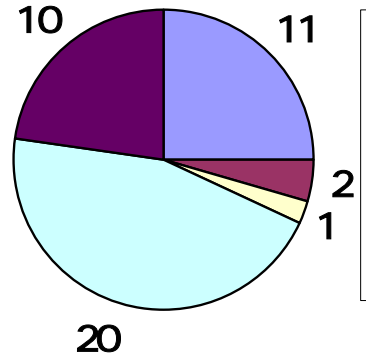

口(1) 作成して住民に配布 している

口(2) 作成しているが住民 には配布していない 口 (3) 作成中である . 3.

(5) 作成していない

图-5 ハザードマップの作成状況

設問22)日頃から浸水や土砂災害の発生の恐れ がある危険箇所を想定して住民に周知しています か。

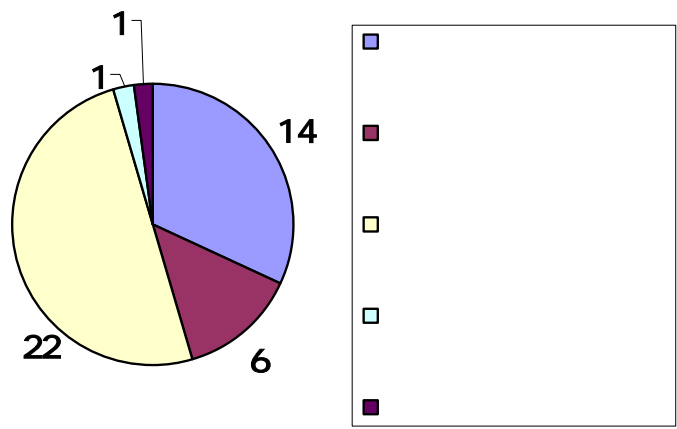

图 -6 危険箇所の把握と周知について

情報が住民に確実に伝達された」と回答している．上記 は防災担当者の主観を含んだ回答ではあるが，行政側の 避難情報の発令タイミングと住民への避難情報の伝達の 確実性には関連があることを示唆していると思われる .

\section{(2) 防災対策としてのリスクコミュニケーション}

图－5は，ハザードマップの作成状況を示したもので ある.設問では, 回答に際してハザードマップの内容や 水準等については特に定義をしていない．

11の自治体 (25\%) がハザードマップを作成して住民 に配布していると回答している．ただし，多くは防災 マップと称し，急傾斜地や地すべり危険箇所，土石流危 険箇所を避難所や医療施設とともに地图上に記載したも のを住民に配布しており，記載内容には大きなばらつき がある . 浸水想定図は, 直轄河川の大淀川 , 小丸川 , 五ヶ瀬川て作成されており，大淀川下流域については， 平成17年度 (台風14号以前) に宮崎市民に配布されてい る.一方，県管理河川での整備はこれからである．㴥方 庁によると，風水害を対象にハザードマップを作成して いる自治体は全体の28. 1\%, 住民に配布している自治体 は24. 2\%(゙ある ${ }^{5)}$.

图 -6は , 危険個所の把握と住民への周知の状況を示 したものである.14の自治体で「危険個所を把握して住 民へ周知している」と回答している．また，6つの自治 


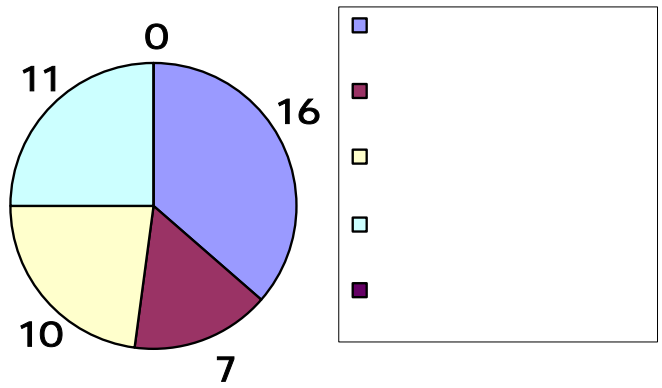

図 - 7 防災訓練の実施状況

体では，「危険箇所の把握は十分ではないが，把握して いる範囲て准民に周知している」と回答している．一方， 半数の自治体は，「災害危険個所を把握はしているもの の住民に十分に周知できていない」と回答している . 今 回の台風14号で人的被害か溌生した6市町村においても 半数の3市町村が「周知は十分でなかった」と評価して いる.㴥方庁によると，地域防災力の評価項目において “リスク把握・評価・被害想定”の項目と“ 住民との情 報共有”は依然として進んでおらず，特に風水害は地震 や火山災害などに比べて低(水準にある ${ }^{6)}$.

図－7と図-8は，防災訓練と防災教育の実施状況を示 したものである . 防災訓練や防災教育の内容については 自治体によって大きな幅があると思われるが，ここでの 回答に際しては, 乥れらの内容や水準等については特に 定義をしていない．

防災訓練を定期的に実施しているのは16の自治体 (36\%) ，不定期を含めて毎年実施しているのは23の自 治体 (52\%) にとどまる . また，防災教育に関しては， 毎年実施しているのは11の自治体 (25\%) で，26の自治 体 (59\%) では防災教育は実施していない.

上述のように, 自治体による災害危険箇所の住民への 周知が十分ではないことや, 防災訓練や防災教育の実施 状況か芳しくないこと，更に，ハザードマップの整備が 進んでいない状況等から考えると，風水害や土砂災害に 関して行政と住民間の日頃からのリスクコミュニケー ションは必ずしも十分とは言えない，災害時の避難行動 を確実なものにするためには, 日頃からのリスクコミュ 二ケーションを通じて防災意識を醇成・維持することが 重要であると考える .

（３）避難施設の整備と自主防災組織について 台風14号時には県内の広い範囲で避難勧告や避難指示 が発令され，多くの住民が避難した . 今回のアンケート 調査では, 約半数の自治体が辟難施設に問題があつたと 回答している.特に, 被害が大きかった自治体ほど避難 施設や経路の問題点を指摘している.

表-2は回答者か記述した問題点のうち, 主要なもの

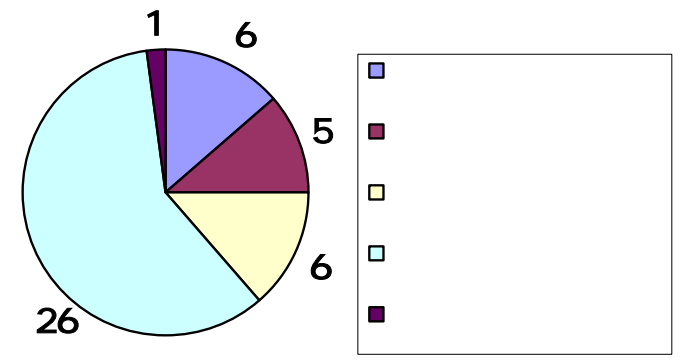

図-8 防災教育の実施状況

表 - 2 避難所の具体的な問題点に関する記述例

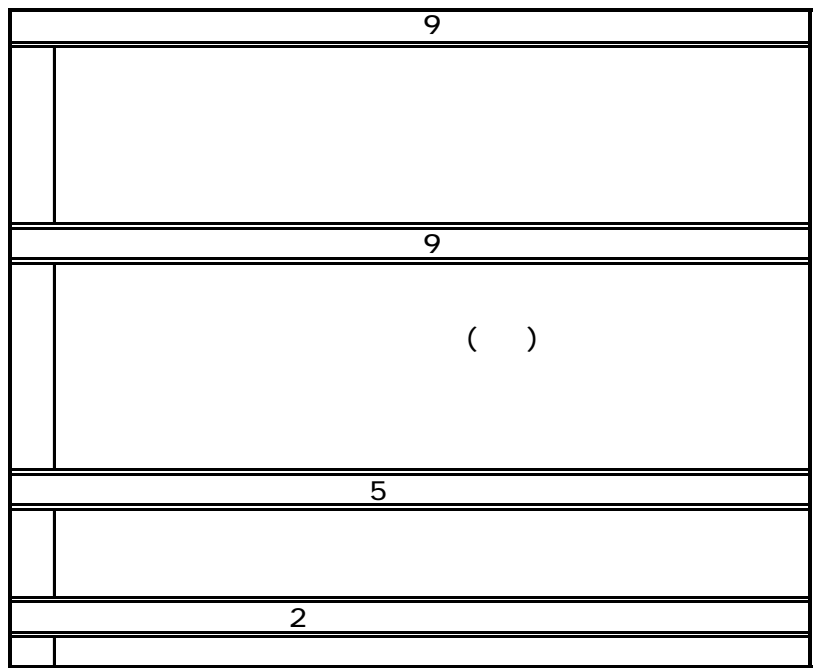

を整理した結果である．避難所の浸水，避難所の直近で の土砂崩れ，避難経路の遮断，避難所の施設不備や老朽 化, 避難所で災害状況か把握できないなど，避難所とし ての機能に重大な支障があるとの指摘が多い. また ，お 年寄りや要介護者などか浰用することを前提とした避難 施設がないことも多く指摘され，災害弱者への対応は非 常に遅れている。

避蜼の主体力地域の事情をよく知る住民であることを 考えると，避難所や避難経路の再設定や見直しに住民が 主体的に関わることは, 行政と住民間のリスクコミュニ ケーションの活性化や地域コミュニティーの強化の観点 から重要であり, 地域防災力の向上にも資するところが 大であると考える

图－9は，台風14号時の自主防災組織（消防団や水防 団を含めて) の機能について示したものである.設問で は機能状況に対する定義はしておらず，ここでは自治体 内を総合した災害対応状況として評価した。

28の自治体で自主防災組織力機能したと回答している 一方で, 16の自治体では自主防災組織力㙨能しなかった （あるいは組織力存在しない）と回答している.自主防 災組織か機能しなかった理由としては，「災害の規模が 
設問31)今回の14号台風で自主防災組織は十 分に機能しましたか。

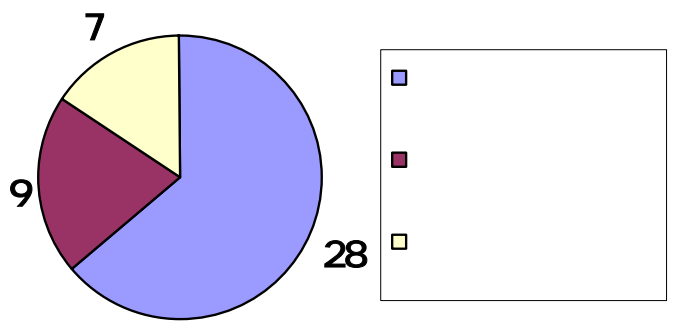

図-9 災害時の自主防災組織の機能について

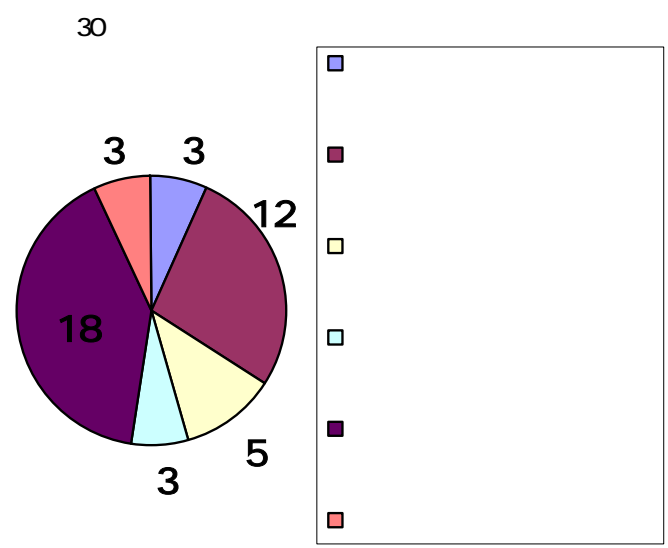

図-10 自主防災組織の組織化につい

大きすぎたため」，「火災等への対応を想定しており自 然災害に対して訓練をしていなかった」，「地区全体が 浸水して対応できなかった」，「電話の不通や道路の寸 断て連絡か取れなかった」，「防災訓練を実施していな いため自主的に活動できなかった」，「青壮年層は勤務 等のため家を不在にし、自主防災隊として組織的に活動 できる体制にない」，「公民館組織としての活動にとど まっている」等か学げられた .

（4）防災管理体制の見直しと強化について

图-10は，今後の自主防災組織の強化について示した ものである . 台風14号災害を教訓に県内の86\%の自治体 が「市町村内全域で自主防災組織を強化したい」と回答 しており，地域防災力の向上には自主防災組織の強化が 非常に重要であると認識している．「自治会単位での災 害図上訓練の実施を呼びかける」(日向市)，「市民自 らか主体となって地域防災に関する課題や懸案事項等の 調査研究を行なう市民委員会を設置している」（日南 市) など，具体的な取組みを始める自治体も出てきてお り実効あるものになることか望まれる .

一方で，「住民に色機(管理)意識をもってもらうよう 行政として働きかけていかなければならないと痛感し た」(高千穂町)，「地域住民の防災意識の向上をさら
設問4)今回の14号台風で災害対策本部や警戒本部等を 組織した場合，光の組織概要 組織長, 組織人数,防災担 当専門家の有無,専門技術者の有無)を二記入〈ださい。

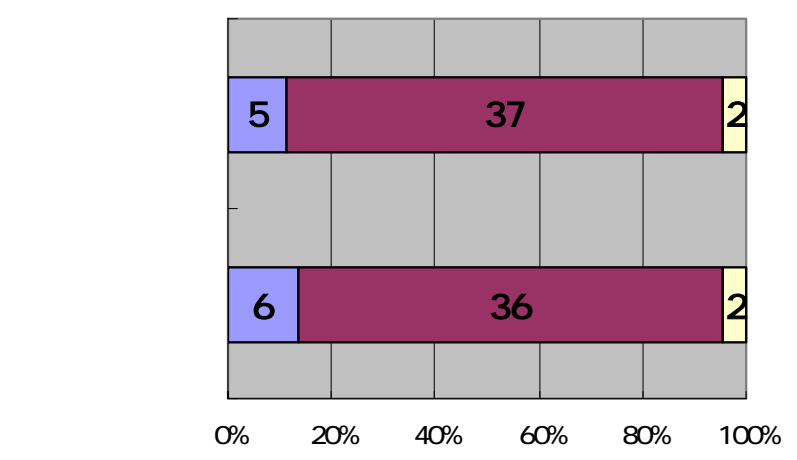

图-11 専門技術者およひ防災専門家の配置

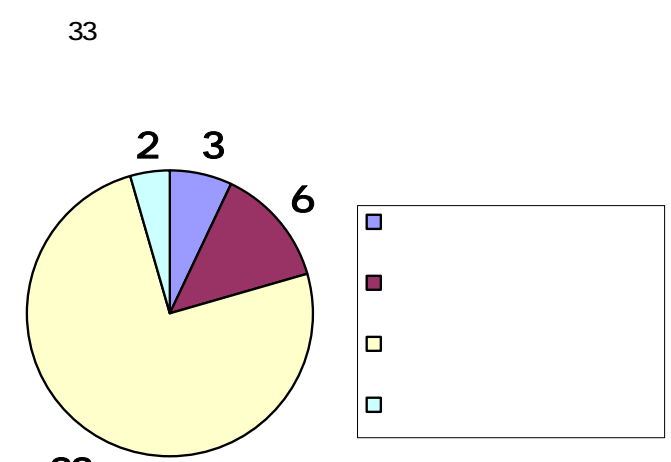

33

图-12 色機管理部門の組織化について

に図っていきたい」(南拫村)，「いかにして住民一人 一人に対して危機的状況を伝えるかがカギである」(宮 崎市)，「地域の高齢化が進み，昼間若者は仕事等で不 在になるので自主防災の活動か灘しい」 (日向市) など， 組織強化を図りたいが具体的な方策に苦慮している自治 体が多い，なお，宮崎県内の市町村の自主防災組織率

(世帯数べース) は60.9\% (平成16年4月1日現在) で, 全国的に見ると平均よりも若干高い数値となってはいる が, 組織率力極めて低い自治体もあり，全体的な組織率 の向上を図る必要がある .

图－11は，災害に対応する専門技術者や防災担当専門 家の有無について示したものである.ここで, 専門技術 者とは「河川や地盤を専門とする技術者」，防災担当専 門家とは「災害対応のための教育や訓練を受けた専門 家」と定義してアンケートに回答してもらった . 専門技 術者や防災担当専門家か淡害対応にあたつた自治体は非 常に少なく，ほとんどの自治体では一般職員か災害対応 にあたっている

消防庁によると，風水害を対象とした防災担当者向け の教育や実技訓練を年 1 回以上実施している市町村は 17. $2 \%$ (地震災害は23.5\%) で, 専門的な知識や訓練を受 けた防災担当者の養成は極めて遅れている5 宮崎県にお 
表 -3 防災担当者が優先度が高いと考える今後の 災害対応

\begin{tabular}{|c|c|c|c|c|c|c|}
\hline $\begin{array}{l}\text { 設問34) 今後の災害対応と } \\
\text { して優先度が高いと思われ } \\
\text { る順に右欄に番号を記入く } \\
\text { ださい }\end{array}$ & 1位 & 2位 & 3位 & 4位 & 5位 & 合計 \\
\hline $\begin{array}{l}\text { 河川施設や治水施設の } \\
\text { 整備, 地盤の嵩上げな } \\
\text { ど中心ととた対応 }\end{array}$ & 22 & 5 & 14 & 0 & 2 & 43 \\
\hline $\begin{array}{l}\text { ハザードマップの作成 } \\
\text { や避難体制の強化を中 } \\
\text { 心とした対応 }\end{array}$ & 15 & 19 & 6 & 3 & 1 & 44 \\
\hline $\begin{array}{l}\text { 住民を中心とした自主 } \\
\text { 防災組織の強化を中心 } \\
\text { とした対応 }\end{array}$ & 6 & 18 & 15 & 0 & 4 & 43 \\
\hline $\begin{array}{l}\text { 土地利用の誘導を中心 } \\
\text { とした対応 }\end{array}$ & 1 & 0 & 3 & 23 & 8 & 35 \\
\hline $\begin{array}{l}\text { 土地利用の規制や禁止 } \\
\text { を中心とした対応 }\end{array}$ & 0 & 2 & 5 & 12 & 19 & 38 \\
\hline
\end{tabular}

いても災害時に適切に対応できる専門技術者や防災担当 専門家の養成は重要な課題である.

図ー12は, 自然災害を含めた危機管理部門の組織化に ついて示したものである.3の自治体 (日向市, 串間 市，日之影町）では色機管理を専門とする体制を既に組 織化していると回答している．また，比較的大きな自治 体 (例えば，宮崎市，都城市，延岡市，西都市) では組 織化を検討するとしている.一方，光の他の自治体では， 色機管理を専門とする体制を組織化することは現時点で は考えていない .

表-3は, 今後の災害対応として優先度か高いと考え る項目に順位を付けて回答してもらった結果を示したも のである . 防災担当者の評価では, 河川施設や治水施設 の整備や地盤の嵩上げなど，いわゆるハードを中心とし た対応を今後も推進することの必要性を第1位に挙げて いる . 次いで, ハザードマップの作成や避難体制の強化， 自主防災組織の強化となっている。一方, 土地利用の誘 導, 規制およひ禁止を中心とした対応は低い順位て評価 されている. 宮崎県内の土石流危険渓流は3, 239渓流 , 急傾斜地崩壊危険箇所は8, 314箇所，地すべり危険箇所 は273箇所と非常に多い7)。また, 台風14号による犠牲 者のうち11名は土砂災害による.アンケート調査時点で の評価は低いが, 土砂災害による物的被害や犠牲者の発 生を防止するためには, 施設整備を中心とした対応と伴 に, ソフト対策の一環として土砂災害特別警戒区域の指 定等を活用した土地利用の誘導・規制を推進することも 減災対策として重要と考える。

\section{4.まとめ}

避蜼勧告や避難指示の客観的な発令基準を整備してい る市町村は少なく，発令のタイミングに問題を残した自 治体が多い、特に，人的被害か発生したにもかかわらず 避難㑑告・指示か発令されなかつた自治体もあり，発令
基準の整備と危険箇所の見直しを急ぐ必要がある．

また，発令の基準值を設定していても，弚の運用に苦 慮している.特に, 適切なタイミングで避難勧告や避難 指示を発令するためには現状よりも狭域 (地区単位て発 领ができる程度) の災害情報が必要であるとの指摘が土 砂災害を被った市町村の多くからなされた .

危険箇所の住民への周知が十分でない市町村が多く， 自治体と住民間て災害リスクや防災情報に関する十分な 情報共有がなされているとは言い難し状況にある．リス クの把握・評価・被害想定や住民との防災情報の共有は 地域防災力の向上において重要な項目であり，日頃のリ スクコミュニケーションを強化して地区の防災情報が共 有できる体制の整備が必要である.

また，避難所の設定や施設の不備，お年寄りや要介護 者を前提とした避難所の不足が多く指摘され，乥の改善 を急ぐ必要がある。

危機管理に対応するための専門技術者や防災専門家が 不足している.災害に関わる専門的な知識や災害対応訓 練を受けた防災担当者の養成が急がれる．

宮崎県では，避難㑑告・避難指示の発令基準の整備， 災害情報の住民への伝達方法, 避難所の選定・運営，災 害時要援護者支援対策等について改善を進めている. 改 善の取組みか実効あるものになることか望まれる .

謝辞 : 本調査にこ協力いただいた宮崎県内市町村の防災 担当者の方々，および宮崎県危機管理局の方々に謝意を 表します．

\section{参考文献}

1) 土木学会 : 平成17年台風14号の記録的豪雨による災害 の調査と減災対策に関する研究, 土木学会台風14号災 害緊急調査団報告，pp. 97，2006年6月

2) 宮崎県 : 平成17年9月4日からの台風第14号の影響によ る大雨の被害状況等について (2006年1月13日午後3時 現在) , htt p: //www. pr ef. minazaki.I g.jp/

3) 辻本哲郎: 平成16年豪雨災害の特徵と抽出される治 水・水防災と水工学の課題, 河川技術論文集, 第11巻, 2005.

4) 牛山素行, 今村文彦, 片山敏孝, 越村俊一 : 豪雨時の 自治体における防災情報の利用，水工学論文集，第47 巻, pp. $349-354,2003$.

5) 総務省消防庁 : 市町村における災害対応の取組状況 (別紙)，2006年3月8日， ht t p: // www. fdnz. go.jp/

6) 総務省消防庁 : 都道府県における平成17年度防災力自 己評価結果（別紙），2006 年1月31日， htt p: //www. fdna. go.jp/

7) 宮崎県土木部 : 宮崎県における災害文化の伝承 , pp. 72 , 2006.

(2006. 9. 30受付) 